\title{
The Value of Propoxyphene
} Hydrochloride (Darvon) ${ }^{\circledR}$ for the Treatment of Hyperhidrosis in the Spinal Cord Injured Patient: An Anecdotal Experience and Case Reports

\author{
Edward A. Tashjian, M.D. and Kenneth J. Richter, D.O. \\ Department of Rehabilitation Medicine, Sinai Hospital of Detroit, 6767 West Outer \\ Drive, Detroit, Michigan 48235, U.S.A.
}

\begin{abstract}
Summary
Hyperhidrosis is a condition affecting the spinal cord injured (SCI) patient that often does not respond well to medical management. While the aetiology of hyperhidrosis in SCI patients is not completely understood, the standard form of treatment is aimed at interrupting the sympathetic cholinergic eccrine sweat glands. It has been our experience in treating this condition that many patients will have a significant decrease in hyperhidrosis using propoxyphene hydrochloride (Darvon) ${ }^{\circledR} 65 \mathrm{mg}$ once or twice per day. Two of these patients are presented. While the mechanism of action is purely speculative, there is evidence to support the concept that opioids may act as a weak ganglionic blocking agent. We have found that a trial of this medication for SCI patients suffering from hyperhidrosis may produce very gratifying results. Further investigation into the treatment of this condition with propoxyphene hydrochloride is indicated.
\end{abstract}

Key words: Hyperhidrosis; Spinal cord injuries; Propoxyphene hydrochloride.

\section{Introduction}

Hyperhidrosis is a condition that often manifests itself in the spinal cord injured (SCI) patient. This profuse diaphoresis presents itself as a therapeutic problem in that it is often resistant to treatment.

The aetiology of hyperhidrosis in SCI patients is not entirely known. The sympathetic eccrine sweat glands of the body are cholinergically innervated. Acetylcholine induced sweat secretion results from a generalised discharge of the sympathetic nervous system. In the intact nervous system, the hypothalamus serves as the thermoregulatory centre of the body (Mountcastle, 1980). Interruption of the spinal cord above the T-9 or T-10 level results in the loss of heat induced sweating below the level of the lesion. In injuries above the C-8 level, the thermoregulatory impulses initiating from the hypothalamus are blocked and sweating in the response to an outside temperature increase is not possible (Baker, 1981). However, patients with injuries to the spinal cord, regardless of whether it is the cervical or thoracic cord that is injured, do experience episodes 
of excessive sweating. This sweating, which is reflex in nature, may be due to either distension of the bowel or bladder or from the impulses transmitted into the isolated spinal cord segment. The hyperhidrosis noted is secondary to the loss of inhibition from centres above the lesion. Often the source of these impulses which affect the spinal cord cannot be determined (Baker, 1981).

Several medications have been used to treat this condition. Mecamylamine (Inversine), ${ }^{\circledR}$ an agent which acts by preventing depolarization of post ganglionic neurons of the autonomic nervous system, is often used. However, it lacks therapeutic specificity and is associated with a number of adverse effects in SCI patients, including hypotension, paralytic ileus and urinary retention (Goodman and Gilman, 1974). Atropine, an anticholinergic, antimuscarinic agent can be used since it prevents the action of acetylcholine on eccrine sweat glands, it also causes impairment of smooth muscle function, especially in the gastrointestinal tract and the bladder. Dryness of the mouth is also noted. Methantheline (Banthine) ${ }^{\circledR}$ and propantheline (Probanthine) ${ }^{\circledR}$ are also anticholinergic, antimuscarinic agents which can be used. Their actions and side effects are similar to Atropine (Halstead and Claus-Walker, 1980).

One of the authors, (KJR), during his training, learned of the anecdotal experience (Carle, 1980) of treating hyperhidrosis with propoxyphene hydrochloride. As a result, many patients had a therapeutic trial of this medication with a beneficial response in a large majority. Recently we have had the opportunity of treating two patients with this problem and because we feel this experience will help others in the management of SCI patients with hyperhidrosis, we are detailing their case reports.

\section{Patient 1}

A 53-year-old man was assaulted during a robbery and suffered multiple stab wounds to his back and left arm. Immediately after being stabbed, the patient collapsed. Initial evaluation found the patient to be suffering from a bilateral pneumothorax, injury to both his left brachial artery and vein, and he had a Brown-Sequard type of neurological deficit. Physical examination showed decreased sensation to pin prick, position sense and vibratory sense below the T-4 level on the right side of his body compared to his left. In addition, the patient suffered from marked paresis on the left below the level of the injury. There was also mild paresis noted of the right lower extremity.

The patient had chest tubes inserted for the treatment of the bilateral pneumothorax, and underwent surgical repair of his left brachial artery with removal of an arteriovenous fistula. He did not require surgery for his thoracic spine. Following stabilisation of his medical condition, the patient began a rehabilitation programme.

Shortly thereafter, the patient began to complain of excessive sweating. His hyperhidrosis became more evident with medical improvement. As his rehabilitation progressed, his hyperhidrosis increased, especially with any physical exertion during therapy. His diaphoresis became so severe that he would carry a towel around his neck most of the day. Because of our anecdotal experience we placed the patient on propoxyphene hydrochloride $65 \mathrm{mg}$ each morning. The next day he experienced less sweating during therapy during daytime but continued to 
suffer from marked diaphoresis at night. Two days later he was placed on propoxyphene hydrochloride $65 \mathrm{mg}$ in the morning and evening which significantly decreased his hyperhidrosis both day and night.

After two weeks on propoxyphene hydrochloride, the medication was discontinued. By the following day, the patient once again started suffering from diaphoresis, both during the day and at night. Propoxyphene hydrochloride 65 mg was restarted twice per day. Once again the patient experienced significant relief. In fact, while on propoxyphene hydrochloride he no longer needed to carry a towel around with him. After a successful course of rehabilitation the patient was discharged ambulating with two standard canes and with minimal complaints of hyperhidrosis. In followup two months after his discharge, he remains on propoxyphene hydrochloride $65 \mathrm{mg}$ twice each day with only minimal complaints of hyperhidrosis.

\section{Patient 2}

A 23-year-old man suffered a gun shot wound to his cervical spine in 1979 which left him a C-6 complete tetraplegic. Over the past 5 years he has been hospitalised and treated for multiple pressure sores of the sacrum, ischium and lateral malleoli, both conservatively and surgically. In addition, he has been treated for a reflex sympathetic dystrophy of his upper extremities with multiple stellate ganglion blocks with excellent results on the right and poor results on the left. The patient was evaluated recently for the complaint of profuse sweating of his head, neck, arms and to a lesser extent, his trunk. His symptoms had begun initially more than 1 year before presentation, but they had become much worse 2 months prior to evaluation. He complained especially that when first rising in the morning from bed he would completely soak the shirt that he had slept in necessitating a change of shirts each morning. A previous trial of propantheline in the treatment of his hyperhidrosis was unsuccessful.

Metrizamide assisted CT scanning of the cervical spinal cord revealed evidence of atrophy of the cord at C5-6 but no evidence of a post traumatic syrinx, which has been reported as a cause of hyperhidrosis in SCI patients (Stanworth, 1982). Further evaluation revealed no identifiable aetiology for this patient's hyperhidrosis.

The patient was placed on propoxyphene hydrochloride $65 \mathrm{mg}$ twice per day. Within two days it was noted that his hyperhidrosis had decreased markedly. In fact, his shirt remained dry upon rising in the morning. One week later, the propoxyphene hydrochloride was discontinued. Within one day, his sweating began to increase and by the second day it was as marked as it was prior to starting treatment. The propoxyphene hydrochloride was restarted and once again his diaphoresis decreased significantly. He has since remained on propoxyphene hydrochloride $65 \mathrm{mg}$ twice a day with continued relief from his hyperhidrosis.

\section{Discussion}

Propoxyphene hydrochloride is a centrally acting narcotic analgesic agent. This opioid has an analgesic efficacy estimated to be one third to one half that of 
codeine (AMA Drug Evaluation, 1980). It has a half life of 6 to 12 hours, being metabolized in the liver and then excreted in the urine. Less than one per cent of the patients experience side effects, most commonly being dizziness, sedation, nausea and vomiting. Although drug dependence potential exists, it is felt to be less than that of codeine (Goodman and Gilman, 1975). However, abuse liability with prescription of this medication must be considered prior to placing a patient on propoxyphene hydrochloride.

The mechanism of action of propoxyphene hydrochloride in the treatment of hyperhidrosis is purely speculative. However, we have found that there is considerable evidence to support the concept that opioids may act as a weak ganglionic blocking agent (Kayaalp and McIsaac, 1970; Zelis, et al., 1974). While the aetiology for this therapeutic effect is uncertain, this fact should not deter one from prescribing a trial of this medication in the treatment of this condition.

We readily admit that propoxyphene hydrochloride does not give clinically significant relief of hyperhidrosis 100 per cent of the time, but we have been impressed with the results of this treatment in a significant majority and feel it warrants being brought to the attention of physicians who are frustrated by the lack of success in treating this troublesome condition. In the 4-year experience of one of the authors (KJR), it has been observed that if the clinical response is to occur, it will be within 1 or 2 days. There is no question that further investigation into the treatment of hyperhidrosis with propoxyphene hydrochloride is indicated. Ultimately a controlled study with a more quantitative measurement of response must be undertaken to substantiate our findings. Until this is completed, we can only suggest that physicians faced with treating a patient with hyperhidrosis consider the use of propoxyphene hydrochloride as one of the medications that may possibly afford the patient some relief from this condition.

\section{Conclusion}

The treatment of hyperhidrosis in SCI patients has proven troblesome to physicans dealing with this problem. In our clinical experience we have found a number of patients who have responded to propoxyphene hydrochloride $65 \mathrm{mg}$ once or twice a day in the treatment of this condition. Although further investigation is necessary, this treatment may be of benefit to the many SCI patients suffering from hyperhidrosis.

\section{Résumé}

Etat dont souffre le patient atteint d'une lésion de la moelle épinière, l'hyperhidrose ne répond pas toujours bien au traitement médical. Bien que l'étiologie des patients souffrant d'une lésion de la moelle épinière ne soit pas complètement comprise, la forme de traitement normale vise à interrompre les glandes sudoripares exocrines cholinergiques sympathiques. Notre expérience du traitement de cet état indique qu'il se produit une diminution significative de l'hyperhidrase chez de nombreux patients traités avec de l'hydrochlorure de propoxyphène [Darvon ( $R$ ) $65 \mathrm{mg}$ une ou deux fois par jour]. Deux de ces patients sont présentés. Bien que le mécanisme d'action soit purement spéculatif, il y a lieu de penser que les opioïdes peuvent agir comme de faibles ganglioplégiques. Nous avons constatu'un essai de ce médicament sur des patients souffrant d'hyperhidrose peut produire des résultats très satisfaisants. De plus amples recherches du traitement de cet état avec de l'hydrochlorure de propoxyphène sont indiquées. 


\section{Zusammenfassung}

Die Hyperhidrose ist ein Zustand, der bei Patienten vorkommt, die an Rückenmarkverletzungen leiden und der sich oft der ärztlichen Behandlung entzieht. Obwohl die Ursache der Hyperhydrose bei Rückenmarkverletzten noch nicht vollkommen erörtert ist, wird bei der üblichen Behandlungsmethode angezielt, die Funktion der sympatischen, cholinergischen, exkretorischen Schweißdrüsen zu unterdrücken. Unserer Erfahrung nach, ist es durch die Verabreichung von $65 \mathrm{mg}$ Propoxyphen Hydrochlorid (Darvon) ${ }^{\circledR}$ einmal oder zweimal täglich, gelungen, die Hyperhidrose bei vielen Patienten herabzusetzen. Der Fall von zwei solcher Patienten wird angeführt. Obwohl der Auswirkungsvorgang vollkommen spekulativ bleibt, darf die Auffassung ausreichend bestätigt werden, daß dabei Opioide einen schwachen Ganglionblock ausüben.

Unsere Erfahrung hat bewiesen, daß die Verabreichung dieser Arznei versuchsweise bei Rückenmarkverletzten, die an Hyperhidrose leiden, sehr befriedigende Ergebnisse leisten kann.

Eine weitere Forschung in die Behandlung dieses Leidens anhand von Propoxyphen Hydrochlorid ist durchaus angezeigt.

\section{References}

AMA Drug Evaluation 1980 4th edition, AMA.

BAKER AB 1981 Clinical Neurology, Revised edition, Harper and Row, Philadelphia.

Carle Terry V 1980 Personal Communication.

Goodman LS, Gilman AG 1975 The Pharmacologic Basis of Therapeutics, 6th edition, MacMillan Publishing Co., Inc., New York.

Halstead LS, Claus-Walker J: Neuroactive Drugs of Choice in Spinal Cord Injury, The Institute for Rehabilitation and Research, Houston, Texas, 1980.

KAYAALP SO, MC ISAAC RJ 1970 Differential blockade and potentiation of transmission in a sympathetic ganglion. Journal of Pharmacology Exp. Ther. 173:193-204.

Mountcastle VB: Medical Physiology, 14th edition, St Louis, C.V. Mosby Company, 1980.

STANWORTH PA 1982 The significance of hyperhidrosis in patients with post-traumatic syringomyelia. Paraplegia 20:282-287.

Zelis R, Mansour EJ, Capone RJ, Mason DT 1974 The cardiovascular effects of morphine. Journal of Clinical Investigation, 54:1247-1258. 